\title{
Comparative chronology of garnet, zircon and monazite in (ultra)high- temperature and -pressure rocks
}

L. TUAL ${ }^{*}{ }^{2}$, M. A. SMIT' ${ }^{2}$, E. KoOIJMAN', M. SCHMITT'

Department of Geosciences, Swedish Museum of Natural History, Stockholm, Sweden. (*lorraine.tual@nrm.se) Department of Earth, Ocean, and Atmospheric Sciences, University of British Columbia, Vancouver, Canada

Age data from accessory minerals are regularly linked to petrological processes such as garnet growth and breakdown via REE signatures. Although this approach appears powerful, gaps in our understandings of REE systematics in high-grade rocks still exist, particularly regarding the degree to which these minerals chemically equilibrate at extreme conditions. To investigate this, we performed comparative chronology and REE analysis of garnet, zircon and monazite in: 1) a fluid-rich, UHP migmatite (W. Norway), and 2) dry felsic UHT granulite xenoliths from the Pamir (Tajikistan).

Zircon and monazite from the UHP migmatites yield a range of $\mathrm{Gd} / \mathrm{Yb}$ values and $\mathrm{U}-(\mathrm{Th}-\mathrm{Pb}$ ages. Although the data show substantial dispersion, the maxima and largest range in $\mathrm{Gd} / \mathrm{Yb}$ is observed for grains yielding $430-422 \mathrm{Ma}$, which brackets the Lu-Hf age of garnet. Accessory minerals in the dry Pamir xenoliths record several discrete growth pulses between 50 and $11 \mathrm{Ma}$. Accessory minerals that are texturally associated with garnet yielded c. $40 \mathrm{Ma}-$ identical to the $\mathrm{Lu}-\mathrm{Hf}$ garnet ages for these samples. Yet, the grains yielded the lowest, not the highest, $\mathrm{Gd} / \mathrm{Yb}$ values.

Despite significant differences in the nature of the samples, their accessory minerals reflect REE equilibrium with garnet. This equilibrium is nevertheless not necessarily reflected by particularly high $\mathrm{Gd} / \mathrm{Yb}$ values. A particularly large range in accessory mineral $\mathrm{Gd} / \mathrm{Yb}$ values, or even the lowest $\mathrm{Gd} / \mathrm{Yb}$ values, may reflect cogenesis with garnet. Likewise, dispersion may be diagnostic of equilibrium rather than disequilibrium among these phases. These observations allow improved petrochronologic interpretations, especially in cases where ageREE records of accessory minerals seem overly complex. 